\title{
Approaching electrical circuit understanding with circuit builder virtual laboratory
}

\author{
Purwoko Haryadi Santoso $^{1^{*}}$, Nino Munawanto ${ }^{2}$ \\ ${ }^{1}$ Department of Physics Education, Universitas Sulawesi Barat, Majene, Sulawesi Barat 91412, Indonesia \\ ${ }^{2}$ Budi Utama Middle School, Sleman, D. I. Yogyakarta 55284, Indonesia \\ *Corresponding Address: purwokoharyadisantoso@unsulbar.ac.id
}

\begin{abstract}
Article Info
\section{Article history:}

Received: February $26^{\text {th }}, 2020$

Accepted: October $21^{\text {st }}, 2020$

Published: October $30^{\text {th }}, 2020$

\section{Keywords:}

Circuit builder;

Electrical circuit;

Student comprehension;

Virtual laboratory.

ABSTRACT

Nowadays, most students are familiar with the notebook for daily use. The compactness and flexibility of the notebook offer more benefits than a PC. The teachers can engage it during teaching physics. Hence, this research had developed an electrical circuit virtual experiment that acts like real experiments. It can be accessed easily by students in their notebooks. This study introduces a flash-based animation Circuit Builder as a simulation designed to help students understand the electrical circuit. This study's purposes were: (1) to analyze the feasibility level of Circuit Builder for enhancing students' electrical circuit mastery and (2) to know the effectiveness of Circuit Builder based on students' electrical circuit mastery. Circuit Builder was developed by 4D (Define, Design, Develop, and Disseminate) model. The feasibility level was analyzed by CVI (Content Validity Index). Then, the effectiveness was tested with effect size. This study proved that the virtual laboratory "Circuit Builder" was feasible in physics class with a moderate effect size. The virtual laboratory could improve students' electrical circuit mastery than doing practices with traditional laboratories.
\end{abstract}

\section{INTRODUCTION}

Notebooks have been used extensively in education. The use of notebooks has been widely applied in schools and universities. In the classroom, it can be used to display animation or a moving image. With animation, it was found that students will get information easier than writing in the textbook (Gusmida \& Islami, 2017; İnce et al., 2015; Utami et al., 2017). While in the lab, a notebook is used as a tool to collect and display data in real-time (Cvjetkovic \& Matijevic, 2016).

Today, notebooks in the laboratory are not only to facilitate students in obtaining experimental data. The computer can be used as an aid for the experiment. It becomes an alternative experiment tool (Douglas et al., 2017; Luna-Moreno et al., 2015; Mottelson \& Hornbæk, 2017). Researchers have developed a notebookbased simulation that students can utilize to experiment like in the real laboratory. Students who study air friction through notebook simulations are as effective as students who studied with traditional methods. The students who study with simulations tend to be more confident than they do not (İnce et al., 2015; Valance et al., 2015).

Software like PhET, interactive science simulations provide virtual appliances found in the laboratory (Correia et al., 2019; Dasilva et al., 2019; Eveline et al., 2019; 
Putranta et al., 2019; Sari et al., 2019). PhET simulations have provided 70 simulations, including the simulation of electric circuits. Through this simulation, students can vary the value of both the resistor and the battery autonomously. Students can also build electric circuits themselves and measure the current and voltage using electrical measuring instruments in their computers. These simulations effectively help students understand the motion of electrons that cannot be observed by students in the laboratory (Siswanto, 2019). Simulation in an electrical circuit experiment is proved to be as effective as hands-on experiments in the laboratory (Rytting et al., 2019; Yuliati et al., 2018).

Many simulations have been implemented to assist students' conceptual understanding of electricity (Arifullah et al., 2020; Eveline et al., 2019; Rahmawati et al., 2020). However, most simulations are produced in the English language that is difficult to be understood by Indonesian students (Perkins et al., 2006; Wieman et al., 2008). Simulation only provides the electrical components named in English (Farrokhnia \& Esmailpour, 2010). This could lead the student to find terms that do not correspond to their textbooks.

A laboratory's existence is quite essential to create challenging physics instruction (Kuliga et al., 2015; Mottelson \& Hornbæk, 2017). Simulation as a substitution for laboratory equipment could be beneficial for the schools, especially for those who have limited equipment. Simulations can be carried out by every student in the class if they have access to their laptops. Therefore, researchers need to develop an electrical circuit simulation that is accommodated with the worksheet and lesson plans.

Besides, many simulations are not equipped with a guide to reaching the learning objectives appropriate to the curriculum of 2013. Teachers cannot just rely on simulation to achieve the learning objectives. A lesson plan and worksheet are much needed to be structured and appropriate with the learning objectives.

The authors developed a simulation named Circuit Builder. The novelty of this study is an electrical circuit simulation developed with the Indonesian language. It will help students that have low skills in English. So, with this improvement, there is no reason to study physics with the physics simulation. Moreover, with this simulation, students can conduct electrical circuit experiments similar to hands-on experiments in the laboratory. Correia et al. (2019), Dasilva et al. (2019), and Putranta et al. (2019) have found that learning physics with a virtual laboratory can improve the students' conceptual understanding. It can be made because students can build the circuit, vary, and measure the simulation quantities. Students can easily open the simulation on their laptops because students do not need to install the simulation.

In this study, we probe the usability of a virtual laboratory Circuit Builder, which incorporates real-life elements (here, the teacher) with virtual electrical components (here, Circuit Builder) to engage students in the laboratory activities. Circuit Builder is a highly immersive virtual laboratory that fosters students' understanding of the electrical circuit. As described in the section results and discussion below, Circuit Builder has been concluded as an effective medium to improve students' electrical circuit understanding topic. Hereby, we propose two research questions in this study:

(1) How to develop a feasible virtual laboratory Circuit Builder for physics learning?

(2) To what extent the virtual laboratory Circuit Builder can improve the students' electrical circuit understanding?

This article commences by describing the methods of this research and summarizing the collection and analysis data technique. Then, we discuss the features owned by the virtual laboratory of Circuit Builder, with 
the flagship feature that is the exciting story of our product. In the last section, we discuss the results of the content validity judgment of the virtual laboratory Circuit Builder and answer the proposed research question to conclude the feasibility of virtual laboratory Circuit Builder.

\section{METHODS}

This is a research and development study where the authors develop the learning media of Circuit Builder and to find out its effectiveness. Products developed in this research include software, lesson plans, and worksheets of Circuit Builder. Those are developed with the 4D model (Thiagarajan et al., 1974). The development steps in this model include defining, designing, developing, and disseminating.

This study is developmental research with a quasi-experimental design to test the effectiveness of the virtual laboratories. This study uses the final score of the conceptual understanding test (post-test) without using the pre-test. Researchers only reviewed the post-test because the goal of this study was to determine the effectiveness of the learning instruments in terms of the achievement of physics passing grades. In this design, there are two groups chosen purposively. The first group, called the control class, is a group taught by direct instruction with a hands-on experiment. Meanwhile, the second group referred to the treatment class is a group taught by Circuit Builder.

The research was conducted at SMA N 6 Yogyakarta, which is a school of research in Yogyakarta. Subjects of the study include two classrooms, i.e., $\mathrm{X} 3$ and $\mathrm{X} 4$, chosen purposively. Class of $\mathrm{X} 3$ is chosen as a control class, and $\mathrm{X} 4$ is a treatment class. Either the control or treatment class has equally 28 students. The research was conducted during the learning of dynamic electricity held in the second semester of the 2015/2016 academic year. Students get physics learning once a week for 135 minutes. Dynamic electricity is scheduled to be taught in three meetings. Before students using the laboratory simulation, students have been taught the concepts of dynamic electricity during two meetings.

The procedure of learning instrument development uses the 4D model, as described in Figure 1.

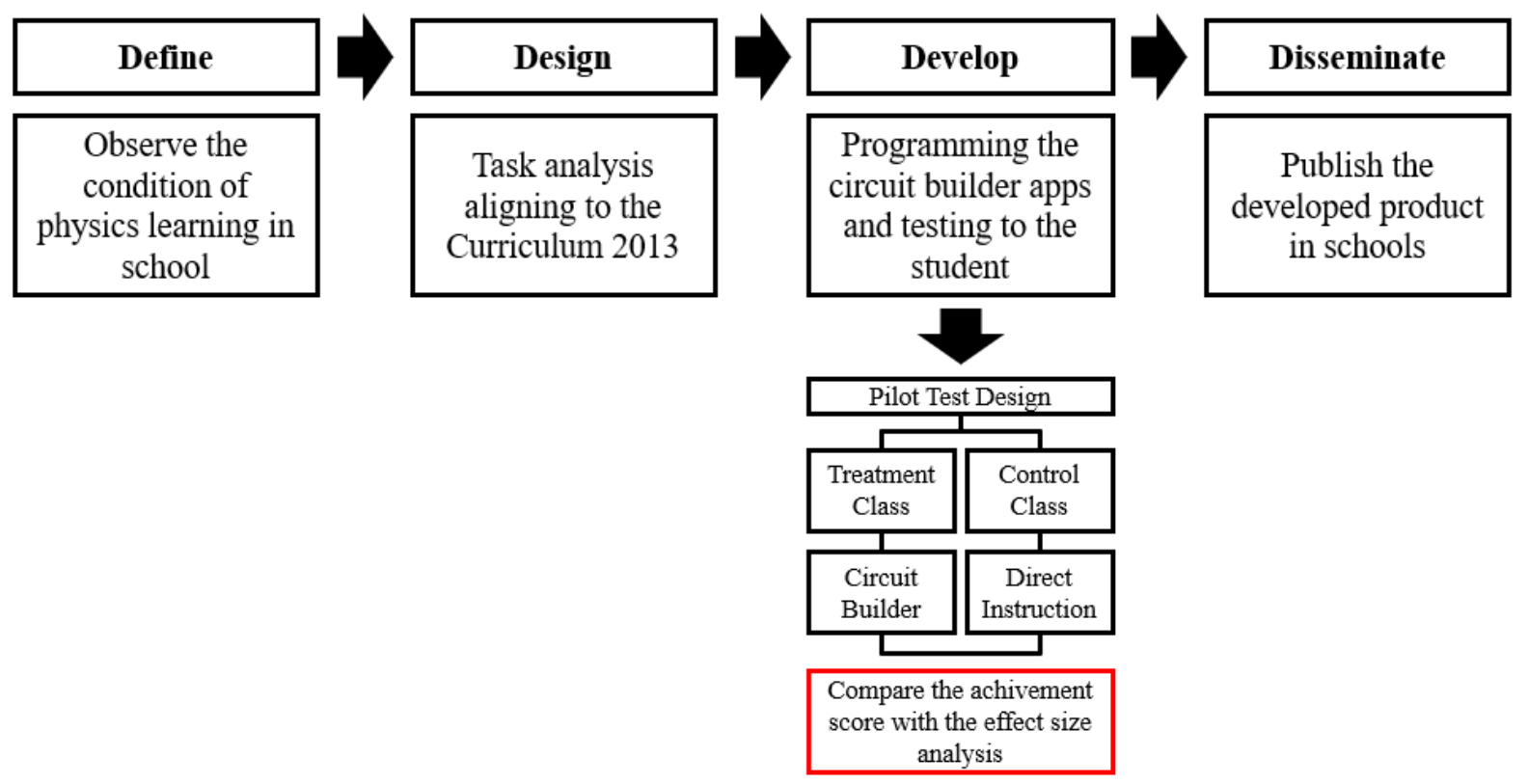

Figure 1. Story board of the research 
Data were gathered with two instruments. Those are a teacher and a student questionnaire. The teacher questionnaire was used to obtain the feasibility of the lesson plan, worksheet, and simulation. The questionnaire contains 20 items as a form of the teacher's response to the developed products. The student questionnaire contains 14 items as a form of student's response after doing Circuit Builder learning. Items provide the feasibility criteria of the worksheet and simulation with understandable diction for students. Experts previously evaluate the questionnaire before being used for the assessment. Thus, we conclude that the questionnaire is a valid and reliable instrument to determine the content validity of the virtual laboratory Circuit Builder.

The Circuit Builder's content validity has to be evaluated before it can be implemented in the pilot test. Content validity means that our Circuit Builder is feasible to promote students' electrical circuit understanding, enhance students' pleasure with physics, and improve physics learning (Simon et al., 2019). It will convince that there are no scientific errors in the visualized media. Moreover, content validity proves that Circuit Builder has covered all of the concept domains in the electrical circuit. The circuit builder's content validity regarding the concept domain of the electrical circuit has been confirmed by the seven professional experts who ranked the questionnaire of content validity. They agreed that Circuit Builder has good content validity and feasible to be implemented in the trial stage.

The feasibility of the learning instruments is determined from the questionnaire of students and teachers. Then, the assessment in the questionnaire is analyzed with Content Validity Ratio (CVR) and Content Validity Index (CVI) by Lawshe (1975). First, questionnaire scores are analyzed using a CVR. After that, the CVR scores obtained on each item are analyzed using CVI. The range of CVR and
CVI value is between -1 and 1 . However, the feasible Circuit Builder should have a CVI score between 0 until 1 . The feasibility value of the instrument can be categorized, as shown in Table 1.

The effectiveness test is based on students who work on the worksheet from both the control class and treatment class. This study uses one sample t-test calculated with SPSS 21. The decision criterion is that the null hypothesis will be rejected if the significance value is less than the significance level $(\alpha)$.

Table 1. Category of the Feasibility

\begin{tabular}{cc}
\hline Value & Category \\
\hline $0,875<X \leq 1$ & Very Good \\
$0,583<X \leq 0,875$ & Good \\
$0,417<X \leq 0,583$ & Average \\
$0,192<X \leq 0,417$ & Bad \\
$0<X \leq 0,192$ & Very Bad \\
\hline & $($ Azwar, 2016)
\end{tabular}

Firstly, the authors test the effectiveness of the control class. Control class is being taught electrical circuit by direct instruction (coded with DI in Figure 1). This test determines whether the direct instruction is effective to teach students' electrical circuit. The students' post-test is analyzed using SPSS 21 based on the passing physics grade (75).

Next, an effectiveness test is conducted on the treatment class. This class is a group that uses Circuit Builder in physics learning (coded with CB in Figure1). This test aims to analyze the effectiveness of the Circuit Builder for enhancing students' mastery in the electrical circuit. The processed data is the students' work to Circuit Builder worksheet with a passing grade (75).

The previous test showed that direct instruction (DI) and Circuit Builder-based learning $(\mathrm{CB})$ was effective or not. If Circuit Builder (CB) was effective and direct instruction (DI) was not, it clearly described that Circuit Builder-based (CB) learning was more effective than direct instruction (DI). Nevertheless, if both were effective, this study had to make further analysis, 
Levene's test with SPSS 21. It compares the mean score between the control and treatment classes. This analysis shows a significant difference between the mean score of the control and treatment classes. Then, if the treatment class score differs from the control class significantly, and it is bigger, it can be concluded that the treatment class is more effective than the control class.

\section{RESULTS AND DISCUSSION Features of Circuit Builder}

Circuit Builder was developed with Actionscript 3.0. It had been designed based on the ease of use for students. The details of each Circuit Builder UI are described below.

a. Splash Screen

It contained flash information about the app's name, the Circuit Builder (see Figure 2).

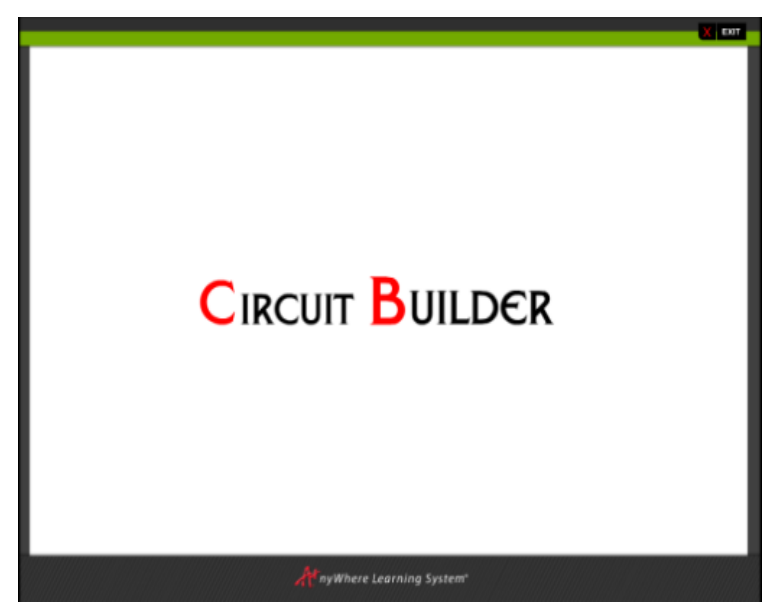

Figure 2. Splash Screen

\section{b. Learning Objective}

Learning outcomes that must be students achieved would be explained in this section (see Figure 3).

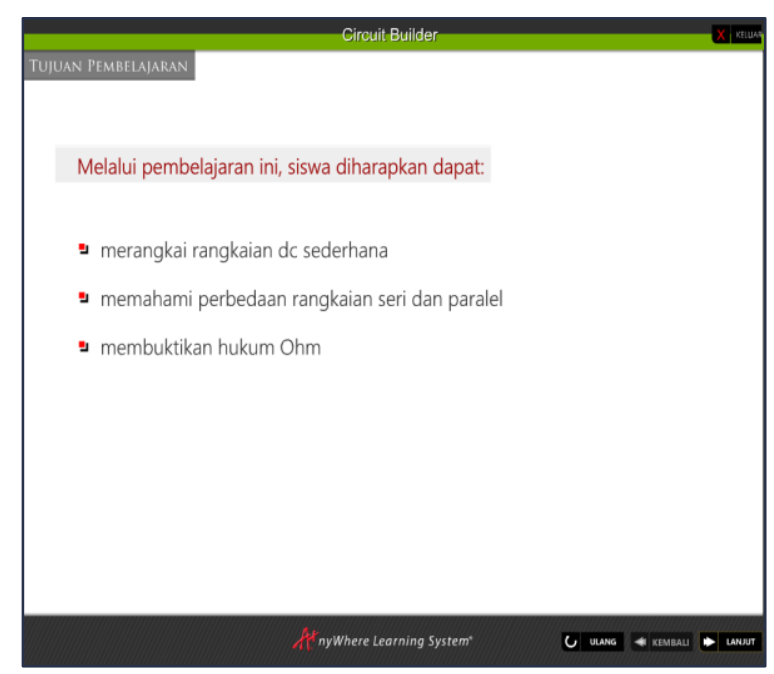

Figure 3. Learning objective

\section{c. Introduction}

It contained a brief description of the electrical circuit to recall students to the matter (see Figure 4).

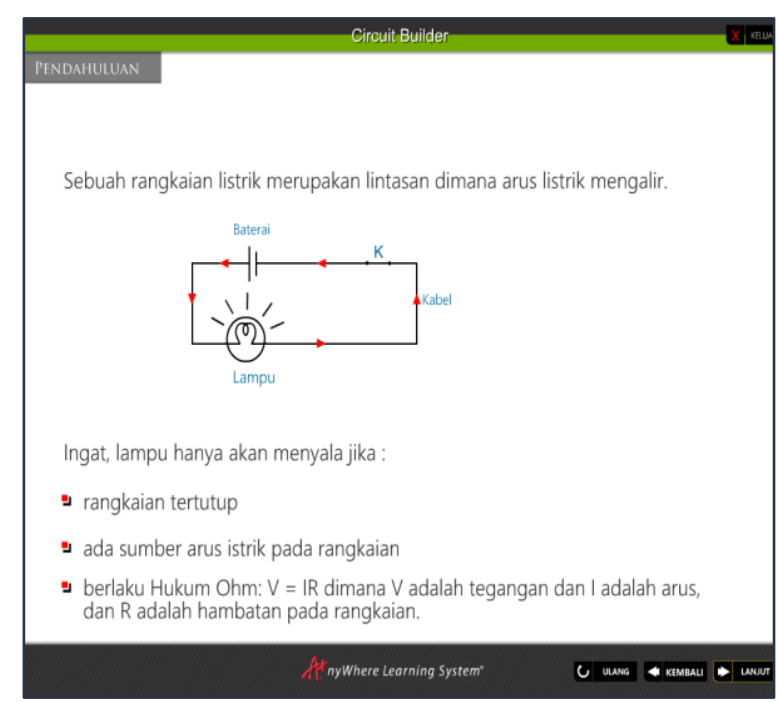

Figure 4. Introduction session

\section{d. Components}

It had information about electrical components used in an experiment, such as cell, wire, bulb, resistor, switch, ammeter, and voltmeter (see Figure 5). 


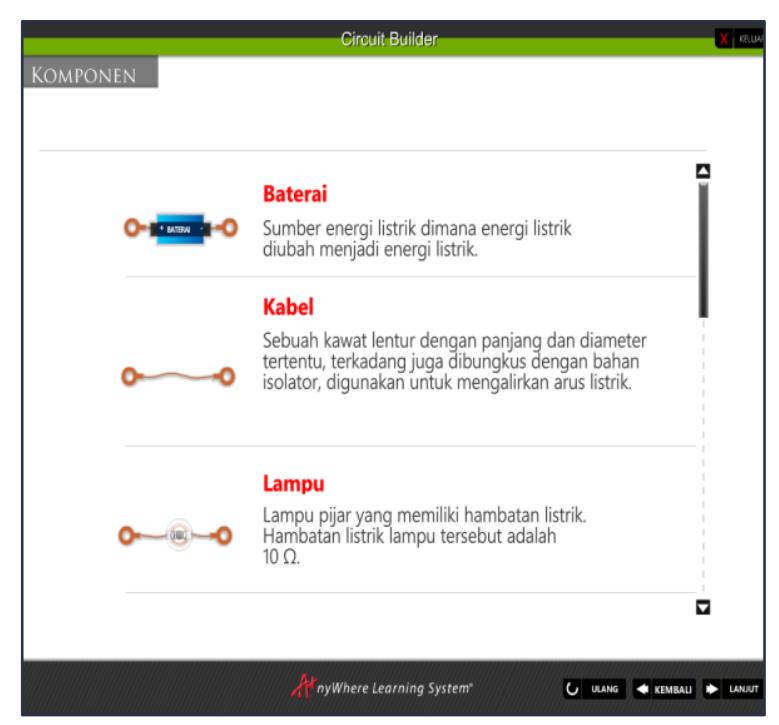

Figure 5. Components user interface

\section{e. About the Tutorial}

It described what we could do with the Circuit Builder (see Figure 6).



Figure 6. About session

\section{f. Circuit}

This was the flagship feature of Circuit Builder. The virtual laboratory UI for the student to build the desired circuit, measure electrical current with an ammeter and measure the voltage with voltmeter autonomously (see Figure 7).

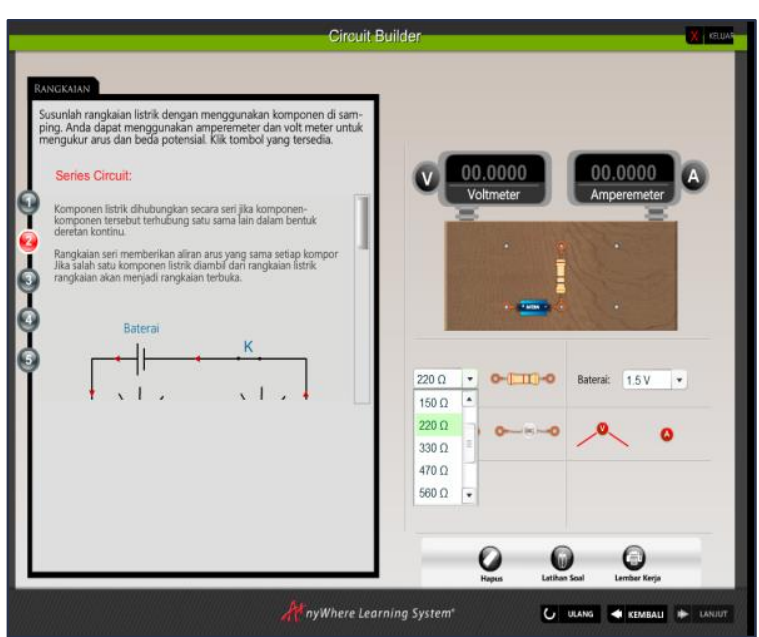

Figure 7. The flagship feature of circuit builder

\section{The Feasibility of the Circuit Builder}

The Circuit Builder's feasibility was analyzed based on an assessment by students and teachers who had used the application in classes.

a. According to Students Assessment

As shown in Table 2, the Circuit Builder gets the average of CVI value 0.72 in the excellent category. It means that Circuit Builder had been able to be understood and approved by the student. Circuit Builder had also been feasible to be used on physics learning. Nevertheless, some aspects became the weaknesses of these apps. It was shown by the two lowest scores, including character and motivation aspects. The monotonous interface might be caused so that students had not be encouraged to study physics.

Table 2. Assessment by students

\begin{tabular}{lllc}
\hline No & Aspect & CVI & Category \\
\hline 1 & Contents & 0.95 & Very Good \\
2 & Pleasure & 0.74 & Good \\
3 & Character & 0.46 & Average \\
4 & Language & 0.81 & Good \\
5 & Motivation & 0.26 & Bad \\
6 & Illustration & 0.85 & Very Good \\
\hline CVI & & $\mathbf{0 . 7 2}$ & GOOD \\
\hline
\end{tabular}




\section{b. According to Teacher Judgement}

Table 3 inferred that Circuit Builder gets the average of CVI value 0.82 to belong to the excellent category. It means that Circuit Builder had been able to be understood and approved by the teacher too. Circuit Builders had also been feasible to be used in physics learning. However, some weaknesses were still found in two aspects, i.e., subject matter and instruction. The teacher said that the contents had not been good enough. There were some misconceptions found in Circuit Builder.

Furthermore, it was still found some active verbs that might be difficult for the student. Even, it could cause misunderstanding. Hence, the score of those aspects was still categorized as average.

Table 3. Judgment by teacher

\begin{tabular}{|c|c|c|c|}
\hline No & Aspect & CVI & Category \\
\hline 1 & Learning process & 0.75 & Good \\
\hline 2 & Curriculum & 0.92 & Very Good \\
\hline 3 & Subject Matter & 0.67 & Average \\
\hline 4 & Color & 0.75 & Good \\
\hline 5 & $\begin{array}{l}\text { Diction and } \\
\text { Language }\end{array}$ & 1 & Very Good \\
\hline 6 & User Interface & 1 & Very Good \\
\hline 7 & Instruction & 0.67 & Average \\
\hline \multicolumn{2}{|c|}{ CVI } & $\mathbf{0 . 8 2}$ & GOOD \\
\hline
\end{tabular}

The Feasibility of Lesson Plan and Worksheet

According to the physics teacher's assessment, the feasibility of the lesson plan and worksheet was analyzed. The teacher agreed that the worksheet of Circuit Builder had been feasible to be used in physics learning in the excellent category. Nevertheless, there were some differences in opinion between teachers and students. Students thought the worksheet's appearance was terrible, but the teacher said the worksheet had a good appearance. It could be caused by a different point of view between them. She thought that the essential feature that must be a presence in the worksheet is the tasks and concepts included inside. If those were present, the appearance aspect is not essential. However, it could be a good suggestion for the authors to revise the appearance, so students would be more interested in studying the worksheet.

The lesson plan of Circuit Builder was also assessed as a feasible learning instrument based on teacher evaluation. She concluded that the lesson plan had a good category. However, she felt that there were no methods to assess learning outcomes. In her opinion, it was needed to give students exercise so that they can solve physics problems. Then, the teacher could measure student achievement.

\section{The Effectiveness of the Circuit Builder}

As shown in Table 4, presents the result of the effectiveness test on direct instruction (control class). This effectiveness was analyzed by t-test and effect size towards students' achievement.

Table 4. One sample t-test in direct instruction

\begin{tabular}{ccccccc}
\hline \multicolumn{4}{c}{ Passing Grade = 75 } \\
\hline & & & Mean & \multicolumn{2}{c}{$95 \%$ Confidence Interval } \\
$\mathrm{t}$ & df & Sig. & Meafference & \multicolumn{2}{c}{ of the Difference } \\
& & & Difference & Lower & Upper \\
3.3 & 27 & $\mathbf{. 0 0 3}$ & 4.08 & 1.54 & 6.61 \\
\hline
\end{tabular}

Then, Table 5 presents the result of the effectiveness test on Circuit Builder based learning (treatment class). This effectiveness was analyzed by a one-sample t-test towards students' attainment based on passing physics grade, and the effect size was also analyzed.

Table 5. One sample t-test in treatment class

\begin{tabular}{|c|c|c|c|c|c|}
\hline \multicolumn{6}{|c|}{ Passing Grade $=75$} \\
\hline \multirow[t]{2}{*}{$\mathrm{t}$} & \multirow[t]{2}{*}{ df } & \multirow[t]{2}{*}{ Sig. } & \multirow[t]{2}{*}{$\begin{array}{c}\text { Mean } \\
\text { Difference }\end{array}$} & \multicolumn{2}{|c|}{$\begin{array}{l}95 \% \text { Confidence Interval } \\
\text { of the Difference }\end{array}$} \\
\hline & & & & & \\
\hline 2.9 & 27 & .004 & 7.03571 & 3.0311 & 11.0403 \\
\hline
\end{tabular}

According to Table 6, direct instruction studied electrical circuits with moderate effect sizes: $\eta=0,64$. The treatment was also effective for studying the electrical circuit with a moderate effect size: $\eta=$ 0,51 .

Table 6. Effect Size Analysis in Each Group

\begin{tabular}{ccccc}
\hline Group & Pre & Post & $\boldsymbol{\eta}$ & Cat. \\
\hline CB & 7.03 & 3.52 & 0.64 & Mod. \\
\hline
\end{tabular}




\begin{tabular}{ccccc}
\hline Group & Pre & Post & $\boldsymbol{\eta}$ & Cat. \\
\hline DI & 4.08 & 3.55 & 0.51 & Mod. \\
\hline
\end{tabular}

Unfortunately, this study found that Circuit Builder-based learning was as effective as direct instruction. It required further analysis to determine the better learning method. Therefore, we should analyze with Levene's test to know the mean difference between direct instruction and Circuit Builder based learning. The analysis result is shown in Table 7.

Table 7. Analysis Result of Levene's Test

\begin{tabular}{clcc}
\hline \multicolumn{2}{c}{ Levene's Test for Equality of } & Variances & Sig. \\
\hline \multirow{2}{*}{ Score } & $\begin{array}{l}\text { Equal variances assumed } \\
\text { Equal variances not assumed }\end{array}$ & 9.955 & $\mathbf{. 0 0 3}$ \\
\hline
\end{tabular}

It was proved that there is a student mastery difference between direct instruction and Circuit Builder based learning significantly. As shown in Table 8, the mean of student mastery in Circuit Builder based learning was also more than Direct Instruction get. Therefore, it could be concluded that the Circuit Builder was more effective than Direct Instruction.

Table 8. Descriptive Statistics of Students' Mastery

\begin{tabular}{llccc}
\hline Class & N & Mean & $\begin{array}{c}\text { Std. } \\
\text { Deviation }\end{array}$ & $\begin{array}{c}\text { Std. Error } \\
\text { Mean }\end{array}$ \\
\hline DI & 28 & $\mathbf{7 9 . 0 8}$ & 6.54 & 1.24 \\
CB & 28 & $\mathbf{8 2 . 0 3}$ & 12.44 & 2.35 \\
\hline
\end{tabular}

These findings showed that learning with computer-based simulation had a benefit for students in learning electrical circuits. Circuit Builder had a considerable impact on students in learning concepts of an electrical circuit. In this study, four aspects assessed students' mastery in an electrical circuit, i.e., collecting data, data analysis, discussion, and conclusion. They were contents included inside the worksheet. According to the student score accumulation, students get the highest score in collecting data and data analysis. It indicated that students were still focused on calculating and formulating physics learning. Students had enough knowledge about the electrical circuit that they had learned before. They were also skilled in building the circuit and measuring using the ammeter and voltmeter. Then, they could apply Ohm's law to analyze the collected data. Nevertheless, the students were still confused about making discussion and conclusion of the experiment, as also showed by Afiana (2017), Mahtari (2020), Ramadan (2020), and Batuyong (2018). It could be caused they did not like the usual working experiment activity in physics class.

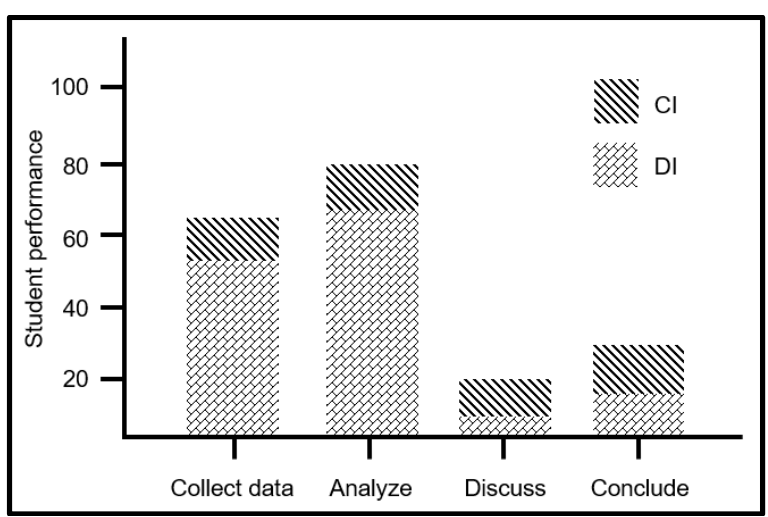

Figure 8. The comparison of students' electrical circuit mastery between CB and DI

Figure 8 illustrates the improvement of students' performance between two groups in terms of indicators of students' mastery in an electrical circuit. It merely indicated that the treatment class $(\mathrm{CB})$ outperformed the control class (DI) in each aspect. CB gets the highest score in the aspect of data analysis and gets lower in the discussion section. It implies that students have the high skill to analyze the data, but they lack experience discussing the data to answer their problems. (Tsai \& Landau, 2008) has found the same result that virtual laboratories could engage students to improve their ability to analyze the data.

\section{CONCLUSION}

According to the research result and analysis of findings during research, it could be concluded that Circuit Builder was feasible to use in physics learning on the electrical circuit. The CVI value is proven 
by 0.72 (good category) from students' assessment and 0.82 (good category) from teacher judgment. Learning the electrical circuit with Circuit Builder was more effective than direct instruction, which was proved by the sig. value 0.03 based on $5 \%$ significance level.

\section{AUTHOR CONTRIBUTIONS}

$\mathrm{PH}$ and NM wrote the manuscript, collected, analysed data and develop the Circuit Builder's. NM reviewing literature and design the storyboard research. $\mathrm{PH}$ conceptualized and criticism.

\section{REFERENCES}

Afiana, E. (2017). Pengembangan modul pembelajaran berbantuan simulasi PhET pada pokok bahasan teori kinetik gas di MA. In Digital Repository Universitas Jember. https://doi.org/10.1242/jcs. 150862

Arifullah, Halim, A., Syukri, M., \& Nurfadilla, E. (2020). The development of student worksheets with PhET assisted to improve student science process skills. Journal of Physics: Conference Series, 1460(1), 1-4. https://doi.org/10.1088/17426596/1460/1/012144

Azwar, S. (2016). Reliabilitas dan validitas aitem. Buletin Psikologi, 3(1), 19-26. https://doi.org/10.22146/bpsi.13381

Batuyong, C. T., \& Antonio, V. V. (2018). Exploring the effect of $\mathrm{PhET}_{\circledast}$ interactive simulation-based activities on students' performance and learning experiences in electromagnetism. Asia Pacific Journal of Multidisciplinary Research, 6(2), 121-131.

Correia, A. P., Koehler, N., Thompson, A., \& Phye, G. (2019). The application of PhET simulation to teach gas behavior on the submicroscopic level: Secondary school students' perceptions. Research in Science and Technological Education, 37(2), 193-217. https://doi.org/10.1080/02635143.2018. 1487834
Cvjetkovic, V. M., \& Matijevic, M. (2016). Overview of architectures with arduino boards as building blocks for data acquisition and control systems. International Journal of Online Engineering, 12(7), 10-17. https://doi.org/10.3991/ijoe.v12i07.581 8

Dasilva, B. E., Kuswanto, H., Wilujeng, I., \& Jumadi. (2019). SSP development with a scaffolding approach assisted by PhET simulation on light refraction to improve students' critical thinking skills and achievement of science process skills. Journal of Physics: Conference Series, 1233(1), 1-12. https://doi.org/10.1088/17426596/1233/1/012044

Douglas, S. S., Aiken, J. M., Greco, E., Schatz, M., \& Lin, S.-Y. (2017). Do-ityourself whiteboard-style physics video lectures. The Physics Teacher, 55(1), 22-24. https://doi.org/10.1119/1.4972492

Eveline, E., Jumadi, Wilujeng, I., \& Kuswanto, H. (2019). The effect of scaffolding approach assisted by PhET simulation on students' conceptual understanding and students' learning independence in physics. Journal of Physics: Conference Series, 1233(1), 1-11. https://doi.org/10.1088/17426596/1233/1/012036

Farrokhnia, M. R., \& Esmailpour, A. (2010). A study on the impact of real, virtual and comprehensive experimenting on students' conceptual understanding of DC electric circuits and their skills in undergraduate electricity laboratory. Procedia - Social and Behavioral Sciences, 2(2), 54745482.

https://doi.org/10.1016/j.sbspro.2010.0 3.893

Gusmida, R., \& Islami, N. (2017). The development of learning media for the kinetic theory of gases using the ADDIE model with augmented reality. Journal of Educational Sciences, 1(1), 
$1-10$.

https://doi.org/10.31258/jes.1.1.p.1-10

İnce, E., Kırbaşlar, F. G., Güneş, Z. Ö., Yaman, Y., Yolcu, Ö., \& Yolcu, E. (2015). An innovative approach in virtual laboratory education: The case of "IUVIRLAB" and relationships between communication skills with the usage of IUVIRLAB. Procedia - Social and Behavioral Sciences, 195(1), 1768-1777.

https://doi.org/10.1016/j.sbspro.2015.0 6.377

Kuliga, S. F., Thrash, T., Dalton, R. C., \& Hölscher, C. (2015). Virtual reality as an empirical research tool - exploring user experience in a real building and a corresponding virtual model. Computers, Environment and Urban Systems, 54(1), 363-375. https://doi.org/10.1016/j.compenvurbsy s.2015.09.006

Lawshe, C. H. (1975). A quantitative approach to content validity. Personnel Psychology, 28(4), 563-575. https://doi.org/10.1111/j.17446570.1975.tb01393.x

Luna-Moreno, D., Espinosa Sánchez, Y. M., Ponce De León, Y. R., Noé Arias, E., \& Garnica Campos, G. (2015). Virtual instrumentation in LabVIEW for multiple optical characterizations on the same opto-mechanical system. Optik, 126(19), 1923-1929. https://doi.org/10.1016/j.ijleo.2015.05. 040

Mahtari, S., Wati, M., Hartini, S., Misbah, M., \& Dewantara, D. (2020). The effectiveness of the student worksheet with PhET simulation used scaffolding question prompt. Journal of Physics: Conference Series, 1422(1), 1-5. https://doi.org/10.1088/17426596/1422/1/012010

Mottelson, A., \& Hornbæk, K. (2017). Virtual reality studies outside the laboratory. Proceedings of the 23rd ACM Symposium on Virtual Reality Software and Technology, Part F1319,
$1-10$.

https://doi.org/10.1145/3139131.31391 41

Perkins, K., Adams, W., Dubson, M., Finkelstein, N., Reid, S., Wieman, C., \& LeMaster, R. (2006). PhET: Interactive simulations for teaching and learning physics. The Physics Teacher, 44(1), 18-23. https://doi.org/10.1119/1.2150754

Putranta, H., Jumadi, \& Wilujeng, I. (2019). Physics learning by PhET simulationassisted using problem based learning (PBL) model to improve students' critical thinking skills in work and energy chapters in MAN 3 Sleman. Asia-Pacific Forum on Science Learning and Teaching, 20(1), 1-44.

Rahmawati, E. N., Jumadi, \& Astuti, D. P. (2020). Development of e-handout assisted by PhET simulation with problem based learning (PBL) model about momentum conservation law and collision to train students' conceptual understanding. Journal of Physics: Conference Series, 1440(1), 1-9. https://doi.org/10.1088/17426596/1440/1/012048

Ramadan, E. M., Jumadi, \& Astuti, D. P. (2020). Application of e-handout based on PhET simulation to improve critical thinking skills and learning independence of high school students. Journal of Physics: Conference Series, 1440(1), $1-8$. https://doi.org/10.1088/17426596/1440/1/012025

Rytting, M., Wright, G., Shumway, S., \& Jensen, J. (2019). Comparison of simulation and hands-on labs in helping high school students learn physics concepts. International Journal of Education, 11(1), 18-28. https://doi.org/10.5296/ije.v11i1.14017

Sari, S., Destianti, S. A., Irwansyah, F. S., Subarkah, C. Z., Aulawi, H., \& Ramdhani, M. A. (2019). Solubility equilibrium learning supported by PhET-SS. Journal of Physics: 
Conference Series, 1157(4), 1-7. https://doi.org/10.1088/17426596/1157/4/042010

Simon, M. N., Prather, E. E., Buxner, S. R., \& Impey, C. D. (2019). The development and validation of the planet formation concept inventory. International Journal of Science Education, 41(17), 2448-2464. https://doi.org/10.1080/09500693.2019. 1685140

Siswanto, J. (2019). Implementasi model IBMR berbantu PhET simulation untuk meningkatkan kemampuan representasi pada pembelajaran fisika. Jurnal Penelitian Pembelajaran Fisika, 10(2), 96-100. https://doi.org/10.26877/jp2f.v10i2.443 7

Thiagarajan, S, Semmel, Dorothy S., Sennel, M. E. (1974). Instructional development for training teachers of exception children. In A sourcebook ERIC. ERIC.

Tsai, S.-H., \& Landau, D. P. (2008). Computer simulations: A window on the static and dynamic properties of simple spin models. American Journal of Physics, 76(4), 445-452. https://doi.org/10.1119/1.2839563
Utami, I. S., Septiyanto, R. F., Wibowo, F. C., \& Suryana, A. (2017). Pengembangan STEM-A (science, technology, engineering, mathematic and animation) berbasis kearifan lokal dalam pembelajaran fisika. Jurnal Ilmiah Pendidikan Fisika Al-Biruni, 6(1), 67-73. https://doi.org/10.24042/jpifalbiruni.v6 i1.1581

Valance, A., Rasmussen, K. R., Ould El Moctar, A., \& Dupont, P. (2015). The physics of Aeolian sand transport. Comptes Rendus Physique, 16(1), (105-117). https://doi.org/10.1016/j.crhy.2015.01. 006

Wieman, C. E., Adams, W. K., \& Perkins, K. K. (2008). PhET: Simulations that enhance learning. Science, 322(5902), 682-683.

https://doi.org/10.1126/science.116194 8

Yuliati, L., Riantoni, C., \& Mufti, N. (2018). Problem solving skills on direct current electricity through inquiry-based learning with PhET simulations. International Journal of Instruction, 11(4), $123-138$. https://doi.org/10.12973/iji.2018.1149a 